\begin{tabular}{|c|c|c|}
\hline Iso & $\begin{array}{c}\text { Bulletin of Pharmaceutical Sciences } \\
\text { Assiut University }\end{array}$ & \\
\hline 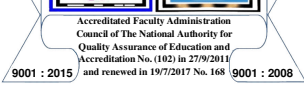 & $\begin{array}{l}\text { Website: http://bpsa.journals.ekb.eg/ } \\
\text { e-mail: bullpharm@aun.edu.eg }\end{array}$ & $\begin{array}{l}\text { BULL. PHARM. SCI. } \\
\text { Assiut Univ. }\end{array}$ \\
\hline
\end{tabular}

\title{
VIRULENCE PROFILE OF HELICOBACTER PYLORI DETECTED IN GASTRIC BIOPSIES OF PATIENTS UNDERGOING ENDOSCOPY IN UPPER EGYPT
}

\author{
Sahar A. Mandour ${ }^{1 *}$, Ahmed Shawkat Abdelmohsen ${ }^{2}$, Mohammed A. Medhat ${ }^{2}$, \\ Doaa Abdeltawab ${ }^{2}$, Ameer Elfarash ${ }^{3}$, Abdulrahman K. Ahmed ${ }^{4}$, Ahmed M. Galal ${ }^{5}$ \\ and Mohamed A. El-Mokhtar ${ }^{6}$ \\ ${ }^{1}$ Department of Microbiology and Immunology, Faculty of Pharmacy, Deraya University, \\ Minia 61111, Egypt \\ ${ }^{2}$ Department of Tropical Medicine and Gastroenterology, Faculty of Medicine Assiut \\ University, Assiut, Egypt \\ ${ }^{3}$ Department of Genetics, Faculty of Agriculture, Assiut University, Assiut, Egypt \\ ${ }^{4}$ Medical Student, Faculty of Medicine, Assiut University, Assiut, Egypt \\ ${ }^{5}$ Postgraduate Student, Department of Surgical Oncology, Sohag Cancer Center, Sohag, Egypt \\ ${ }^{6}$ Department of Medical Microbiology and Immunology, Faculty of Medicine, Assiut \\ University, Assiut, Egypt
}

\begin{abstract}
Background: Helicobacter pylori (H. pylori) is a common cause of gastric ulcers and is a risk factor for gastric carcinoma. Little data are available about the characters of H. pylori causing infections in patients from Upper Egypt. Therefore, the aim of this study was to investigate the frequency of $H$. pylori infection in Egyptian patients undergoing endoscopy and complaining of persistent upper gastrointestinal symptoms directly in biopsy specimens using PCR technique and to study the associated virulence-related genes in H. pylori positive samples. Materials and Methods: One hundred and twenty gastric biopsy specimens were collected from Egyptian patients admitted to Assiut University Hospital and complaining of persistent upper gastrointestinal symptoms. H. pylori DNA was extracted for molecular identification by PCR. Positive samples were further analyzed to investigate the presence of different virulence-related genes and gene combinations. Results: H. pylori was detected in 92/120 (76.6\%) of collected biopsies. All strains carried the vacA sl subtype. The prevalence of the virulence genes cagA, cagE, iceA1, iceA2 and oipA were 79 (84.8\%), 41(44.5\%), 69 (75\%), 44 (47.8\%), and $55(59.7 \%)$ of the H. pylori positive samples, respectively. Genetic analysis showed that $H$. pylori were grouped into 29 different genotype combinations. The s1/m1/i1/d1/c1/cagA/iceA1/oipA genotype was the most predominant. Conclusion: Our results show a high frequency of $H$. pylori infections among Egyptian patients with gastrointestinal symptoms. The s1/m1/il vacA hybrid is the most prevalent subtype. The distribution of the different virulence-related genes shows alarming rates of cagA, cagE, iceA1, iceA2 and oipA. Careful monitory of $H$. pylori infections and investigation of their genetic characters should be carried out to control the spread of the virulent strains.
\end{abstract}

\section{INTRODUCTION}

It was concluded more than a century ago that there is a certain type of bacteria that could be detected in the human's stomach ${ }^{1}$. Twenty years ago, Barry Marshall and Robin Warren successfully isolated a spiral bacterial species' from the human's stomach recognized as Helicobacter pylori ${ }^{2}$. H. pylori is a Gramnegative, spiral shape, microaerophilic

Received in 5/3/2021 \& Accepted in 26/3/2021 
bacterium that commonly colonizes the human gastric mucosa during childhood and can persist for whole of life leading to inflammation of the gastric mucosa with no successful extermination therapy ${ }^{2 \& 3}$.

About half of the world's population are estimated to be colonized with $H$. pylori, the major modes of transmission of infection are fecal-oral or oral-oral; however, there is another indirect mode of transmission through drinking water and other environmental sources ${ }^{4}$. Recently, animals such as cows, sheep, and goats were reported to participate in the transmission of $H$. pylori infections ${ }^{5}$. $H$. pylori is responsible for many gastro-duodenal diseases with distinct clinical symptoms, including dyspepsia, gastric atrophy, gastritis and peptic ulcer, gastric adenocarcinoma in addition to primary gastric B-cell lymphoma ${ }^{4,6 \& 7}$.

The virulence factors of $H$. pylori bacteria are the main factor of such diseases ${ }^{8 \& 9}$. The presence of a bundle of pathogenic genes in $H$. pylori of the stomach biopsies, provides conditions for oncological processes in this area ${ }^{10}$. In gastric epithelial cells, the ability of the bacteria to colonize, adhere, and invade the mucosa are supported by the presence of different virulence-related genes ${ }^{5}$.

There are two important novel virulence $g$ enes, vacuolating cytotoxin A ( $\operatorname{vac} A)$ and cytotoxin - associated gene A ( $\operatorname{cagA})$, which are associated with severe clinical manifestations such as gastro-duodenal ulcers and gastric adenocarcinoma, $a^{3,5 \& 11}$. They are considered as factors affecting colonization efficiency ${ }^{8}$. Moreover, the $\operatorname{cagA}$ gene encoding a protein involved in the expression of interleukin 8 in gastric epithelial cells ${ }^{12}$. Also, it influences the host cell in many ways, such as the formation of gastric epithelium cell, cytoskeleton transition, and influencing cell proliferation ${ }^{5}$.

The vacA gene consists of 5 polymorphic regions including signal regions ( $s 1$ or $s 2$ type), middle regions $(\mathrm{ml} / \mathrm{m} 2)$, intermediate $(i 1 / i 2)$, deletion $(d 1 / d 2)$ and $(c 1 / c 2)^{5 \& 13}$. Vacuolating toxin $v a c A$ is generated by $(s 1 / m 1 / i 1)$ type strains, causing progressive vacuolation and gastric epithelium injury $^{1 \& 3}$.

There are two main allelic variants of the epithelium antigen (iceA) gene: iceAl and ice $A 2^{5}$. These genes are induced by contact with the epithelium antigen ${ }^{5,13 \& 14}$. Outer inflammatory protein (oipA) induced by contact with blood group antigen-binding adhesion $(b a b A)$ and the epithelium antigen (ice $A)^{5}$. $B a b A$ gene enhances the IL- 8 response, leading to increased inflammation of the mucosa ${ }^{8}$. Ilver, et al. ${ }^{15}$ identified this gene as it is involved in the binding activity between bacterial adhesion and Lewis b blood group antigens on the gastric epithelium of human host cells, as well as related with duodenal ulcer. This study aimed to investigate the frequency of $H$. pylori infections in Egyptian patients undergoing endoscopy and complaining of persistent upper gastrointestinal symptoms directly in biopsy specimens using PCR technique and to study the associated virulence-related genes in $H$. pylori positive samples.

\section{MATERIALS AND METHODS}

\section{Patients selection}

Biopsy specimens were obtained from 120 patients who performed esophago-gastroduodendoscopy. Of them $74(61.6 \%)$ showed $H$. pylori-positive stool antigen test. They were complaining of persistent upper gastrointestinal symptoms (GIT) e.g. epigastric pain, early satiety, postprandial upper abdominal distension, nausea, and repeated vomiting at GI endoscopy unit in Al-Rajhi University Hospital, Assiut, Upper Egypt.

The following patients were excluded from the study; pregnant women, children under 18 years, patients with previous upper GI surgery, severely sick individuals, those who have had gastrointestinal bleeding in the past month, and those who refused to sign the consent form voluntarily.

\section{Specimen collection}

Two gastric biopsies, approximately $2 \pm 3$ $\mathrm{cm}$ (one biopsy from the antrum, and the other from the greater curvature of the corpus) were collected and underwent endoscopy examination and rapid urease test (RUT) after evaluation by experienced gastroenterologists at Al-Rajhi University Hospital, Assiut University, Upper Egypt in the period between January and November 2019. 


\section{Processing of the gastric biopsies}

All gastric biopsy samples were analyzed routinely by RUT as part of the gastroenterology outpatient service of the hospital. Care was taken to ensure that the patients did not receive eradication therapy for the $H$. pylori in the last two months, antibiotics, antisecretory drugs, especially proton pump inhibitors (PPI) in the last two weeks or receiving bismuth-containing regimens. Biopsy specimens were used for molecular examination ${ }^{2}$.

\section{DNA extraction}

Genomic DNA of $H$. pylori was extracted from the biopsy specimens using the QIAamp DNeasy Blood and Tissue Kits (Qiagen, Germany) according to the instructions of the manufacturer and stored at $-20^{\circ} \mathrm{C}$. Extracted DNA was used for subsequent PCR experiments.
Detection of $H$. pylori and analysis of the virulence-related genes

PCR amplification of the vacA gene was used for the detection of $H$. pylori in biopsy samples ${ }^{16}$. In addition, the various subtypes of vacA alleles (s, $\mathrm{m}, \mathrm{i}, \mathrm{d}, \mathrm{c}$ regions) were determined. The presence of different virulence-related genes; $\operatorname{cag} A, \operatorname{cag} E$, main allelic variants of iceA gene are iceAland iceA2, oipA as well as babA2 was examined. Generally, PCR reaction conditions were carried out using the Dream Taq PCR Master Mix (Thermo Fisher Scientific, USA) in a final volume of $25 \mu \mathrm{L}$ containing $5 \mathrm{ul}$ of extracted DNA, $0.5 \mathrm{ul}$ of $10 \mathrm{mM}$ of each primer. The reaction conditions were as follow: $95^{\circ} \mathrm{C}$ for 4 minutes, 40 cycles of $95^{\circ} \mathrm{C}$ for 60 second, annealing for 45 second and according to temperatures reported in (Table 1), extension at $72^{\circ} \mathrm{C}$ for 30 second, and a final extension at $72^{\circ} \mathrm{C}$ for 10 minutes.

Table 1: Primers used for amplification of virulence-related genes.

\begin{tabular}{|c|c|c|c|c|c|c|}
\hline \multicolumn{3}{|c|}{ Target genes } & Primer 5' 3' sequence & Annealing & Product size & Ref \\
\hline 1,2 & \multirow{8}{*}{$\begin{array}{c}\text { vac A } \\
\text { allelic } \\
\text { variants }\end{array}$} & $s 1 / s 2$ & $\begin{array}{l}\text { F: ATGGAAATACAACAAACACAC } \\
\text { R: CTGCTTGAATGCGCCAAAC }\end{array}$ & 45 & $259 / 286$ & 18 \\
\hline 3,4 & & $\begin{array}{l}m 1 / \\
m 2\end{array}$ & $\begin{array}{l}\text { F: CAATCTGTCCAATCAAGCGAG } \\
\text { R: GCGTCAAAATAATTCCAAGG }\end{array}$ & 58 & $567 / 642$ & 18 \\
\hline 5 & & il & F: GTTGGGATTGGGGGAATGCCG & \multirow{2}{*}{58} & 426 & \multirow{2}{*}{19} \\
\hline 6 & & $i 2$ & R: TTAATTTAACGCTGTTTGAAG & & 432 & \\
\hline 7 & & $d 1$ & F: ACTAATATTGGCACACTGGATTTG & \multirow{2}{*}{53} & $367-379$ & \multirow{2}{*}{20} \\
\hline 8 & & $d 2$ & R: CTCGCTTGATTGGACAGATTG & & 298 & \\
\hline 9 & & $c 1$ & $\begin{array}{l}\text { F: ATCATYSGTTATGRHAATGTT TCT } \\
\text { R: TTATGCTCTAAACTGGCTA }\end{array}$ & \multirow{2}{*}{55} & \multirow{2}{*}{$600-700$} & \multirow{2}{*}{20} \\
\hline 10 & & $c 2$ & $\begin{array}{l}\text { F: ATTATAATTTAGTAGGAGTGC AAG G } \\
\text { R:TTA TGC TCT AAA CTG GCT A }\end{array}$ & & & \\
\hline 11 & \multicolumn{2}{|c|}{$\operatorname{cag} A$} & $\begin{array}{l}\text { F: AATACACCAACGCCTCCAAG } \\
\text { R: TTGTTGGCGCTTGCTCTC }\end{array}$ & 55 & 400 & 3 \\
\hline 12 & \multicolumn{2}{|c|}{$\operatorname{cag} E$} & $\begin{array}{l}\text { F: TGAAAACTTCAAGGATAGGATAGAGC } \\
\text { R: GCCTAGCGTAATATCACCATTACCC }\end{array}$ & 54 & 508 & 5 \\
\hline 13 & \multicolumn{2}{|c|}{ iceAl } & $\begin{array}{l}\text { F: GTGTTTTTAACCAAAGTATC } \\
\text { R: CTATAGCCASTYTCTTTGCA }\end{array}$ & 55 & 247 & 5 \\
\hline 14 & \multicolumn{2}{|c|}{ iceA2 } & $\begin{array}{l}\text { F: GTTGGGTATATCACAATTTAT } \\
\text { R: TTRCCCTATTTTCTAGTAGGT }\end{array}$ & 55 & 229/334 & 5 \\
\hline 15 & \multicolumn{2}{|c|}{ oipA } & $\begin{array}{l}\text { F: GTTTTTGATGCATGGGATTT } \\
\text { R: GTGCATCTCTTATGGCTTT }\end{array}$ & 55 & 401 & 5 \\
\hline 16 & \multicolumn{2}{|c|}{$b a b A 2$} & $\begin{array}{l}\text { F: CCAAACGAAACAAAAAGCGT } \\
\text { R: GCTTGTGTAAAAGCCGTCGT }\end{array}$ & 55 & 271 & 5 \\
\hline
\end{tabular}

Abbreviations: $(v a c A)$ : (vacuolating cytotoxin or pore forming toxin), vacA alleles: signal regions ( $s 1$ and $s 2$ ), mid-region ( $m l$ and $m 2$ ) alleles, intermediate region $(i 1, i 2)$, deletion $(d 1, d 2),(c 1, c 2)$ indicates no deletion, cagA: (cytotoxin-associated gene), cagE: (encoding a protein involved in the process of interleukin 8 expression in gastric epithelial cells), iceA1, (iceA2): (epithelium antigen) main allelic variants of iceA gene. (oipA): (outer inflammatory protein), (babA2): (blood group antigen-binding adhesion. 
The amplified products were visualized by electrophoresis in $1.5 \%$ agarose gels stained with Gel Red ${ }^{\mathrm{TM}}$. Table 1 summarizes the list of the used primers and their sequences. Positive and negative controls were evaluated with test samples. Phylogenetic grouping profile of the isolates was done by using the software package MVSP and genetic similarities were computed using the Dice coefficient of similarity of $\mathrm{Nei}$ and $\mathrm{Li}^{17}$.

\section{Statistical Analysis}

The results are presented as frequency with percentage. We tested for differences between study groups using the MannWhitney $U$ test, Wilcoxon test, and one-way ANOVA using SPSS (IBM SPSS Statistics for Windows, Version 22, NY, USA). A p value of $<0.05$ was considered as statistically significant.

\section{RESULTS AND DISCUSSION}

\section{Results}

\section{Identification of $\boldsymbol{H}$. pylori}

During the study period, 120 patients were enrolled. The presence of $H$. pylori was determined by detection of the vacA gene by PCR directly from the biopsy specimens. A total of 92/120 (76.6\%) samples tested positive for H.pylori. Patient age ranged from 18 to 67 years old.

\section{Distribution of the vacA allelic subtypes}

Various subtypes of the $v a c A$ gene alleles $(s 1, s 2, m 1, m 2, i 1, i 2, d 1, d 2, c 1$, and $c 2$ ) were observed using PCR assay. All samples 92 $(100 \%)$ carried the sl genotype of vacA. Similarly, vacA $i 1$ of the $i$ region and vacA $\mathrm{ml}$ genotype of the $m$ region, were the most predominant genotypes; they were detected in $85(92.4 \%)$ and $66(71.7 \%)$ of the positive samples, respectively (Table 2).

Table 2: The distribution rate of the vacA alleles among $H$. pylori positive samples.

\begin{tabular}{||c|c|c||}
\hline \multirow{2}{*}{ vacA genotype } & \multicolumn{2}{|c|}{$\begin{array}{c}\text { H. pylori positive } \\
\text { cases }\end{array}$} \\
\cline { 2 - 3 } & $\mathrm{N}=92$ & $(100 \%)$ \\
\hline$v a c A s 1$ & 92 & 100 \\
\hline$v a c A s 2$ & 2 & 2.2 \\
\hline$v a A m 1$ & 66 & 71.7 \\
\hline$v a c A m 2$ & 23 & 25 \\
\hline$v a c A i 1$ & 85 & 92.4 \\
\hline$v a c A i 2$ & 3 & 3.3 \\
\hline$v a c A d 1$ & 56 & 60.8 \\
\hline$v a c A d 2$ & 7 & 7.6 \\
\hline$v a c A c 1$ & 33 & 35.8 \\
\hline$v a c A c 2$ & 2 & 2.1 \\
\hline
\end{tabular}

The genotypes of vacA were evaluated on the basis of five polymorphic regions: the $s, i$, $m, d$ and $c$ regions. The total vacA $(s 1, s 2)$, $(m 1, m 2),(i 1, i 2),(d 1, d 2)$, and $(c 1, c 2)$, regions were amplified in 92 (100\%), 83 (90.2\%), 88 (95.6\%), $63(68.4 \%)$ and $35(38 \%)$ in the $H$. pylori positive specimens, respectively (Fig. 1).

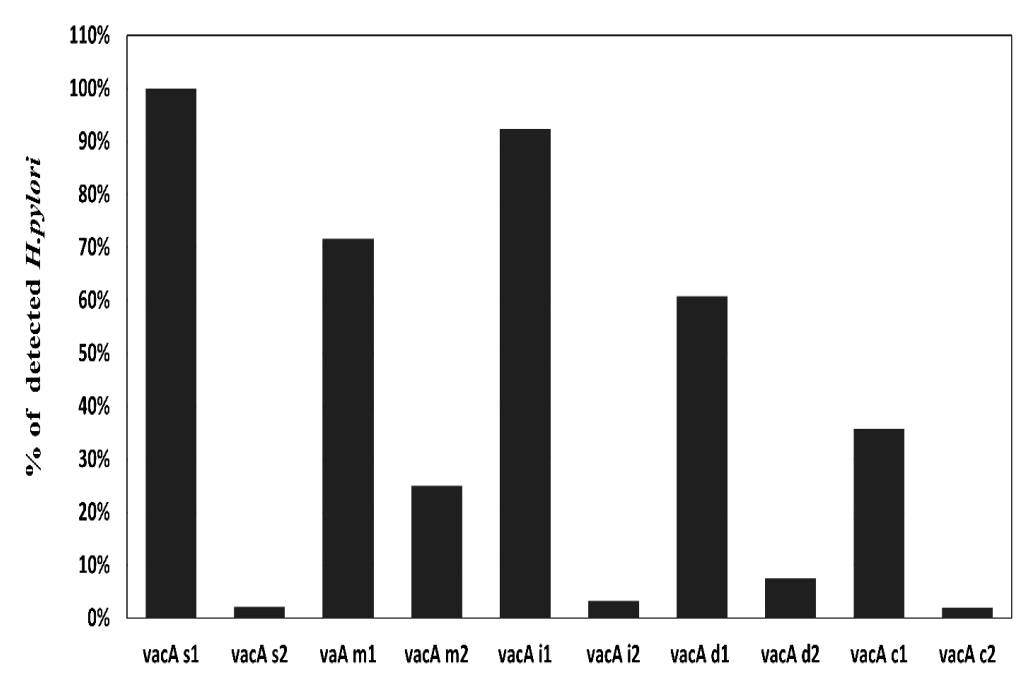

Fig. 1: The prevalence of the vacA alleles among detected H. Pylori. 
Analysis of all vacA subtypes showed that the $s 1 / m 1 / i 1$ hybrid was the most prevalent subtype $61(66.3 \%)$ (Table 3). The distribution rate of the vacA $i$ subtype among the $s$ and $m$ regions were $61(66.3 \%), 18(19.5 \%)$ and 2 (2.1\%) of vacA $s 1 / m 1$, vacA $s 1 / m 2$, and vacA $s 2 / m 2$ genotype strains respectively (Table 3 , Fig. 1). However, none of the examined strains exhibited the $s 2 / m 1$ vacA genotype.

Table 3: Association between the $i$ region of $v a c A$ among the $s$ and $m$ regions of $v a c A$ alleles.

\begin{tabular}{|c|c|c|c|c|c|}
\hline \multirow{2}{*}{$\begin{array}{c}\text { vacA } \\
\text { subtype }\end{array}$} & \multicolumn{2}{|c|}{$\overline{i 1}$} & \multicolumn{2}{|c|}{$i 2$} & \multirow{2}{*}{$\begin{array}{c}\mathrm{P} \\
\text { value }\end{array}$} \\
\hline & No. & $\%$ & No. & $\%$ & \\
\hline $\operatorname{sim} 1$ & 61 & 66.3 & 3 & 32.6 & \multirow{4}{*}{$\begin{array}{c}p< \\
0.005\end{array}$} \\
\hline $\operatorname{sim} 2$ & 18 & 19.5 & 0 & 0 & \\
\hline$s 2 m 1$ & 0 & 0 & 0 & 0 & \\
\hline$s 2 m 2$ & 2 & 2.1 & 0 & 0 & \\
\hline
\end{tabular}

\section{Prevalence of different virulence-related genes}

The distribution of different virulence genes among the $H$. pylori positive gastric biopsy samples showed highest levels for cagA,
cagE, iceAl, iceA2 and oipA. They were detected in 79 (85.8\%), 41(44.5\%), 69 (75\%), $44(47.8 \%)$, and $55(59.7 \%)$ of H. pylori positive gastric biopsy samples, respectively. On the other hand, babA2 was the least frequently detected gene $25(27.1 \%)$, as shown in (Fig. 2).

Moreover, we compared the genetic profile of the virulence-related genes among the positive samples and our results showed the predominance of Profile 1 (observed in 21 samples) which carries 8 genes; s1/m1/il/d1/cl/cagA/iceAl/oipA, followed by profile 2 (observed in 9 samples) which also carries a similar set of 8 genes; $s 1, m l, i l$, d1,cagA,iceA1, oipA, babA2. In contrast, the least prevalent genotypes were "Profile 19" to "Profile 29" which were recorded in only one sample. Two profiles (Profile 23 and Profile 24) carried 10 mixed virulence genes. Other profiles showed variable frequencies and are listed in (Table 4). The genetic relatedness among the different 29 profiles based on the pattern of the presence of the different combinations of the virulence- related genes shows different clusters (Fig. 3).

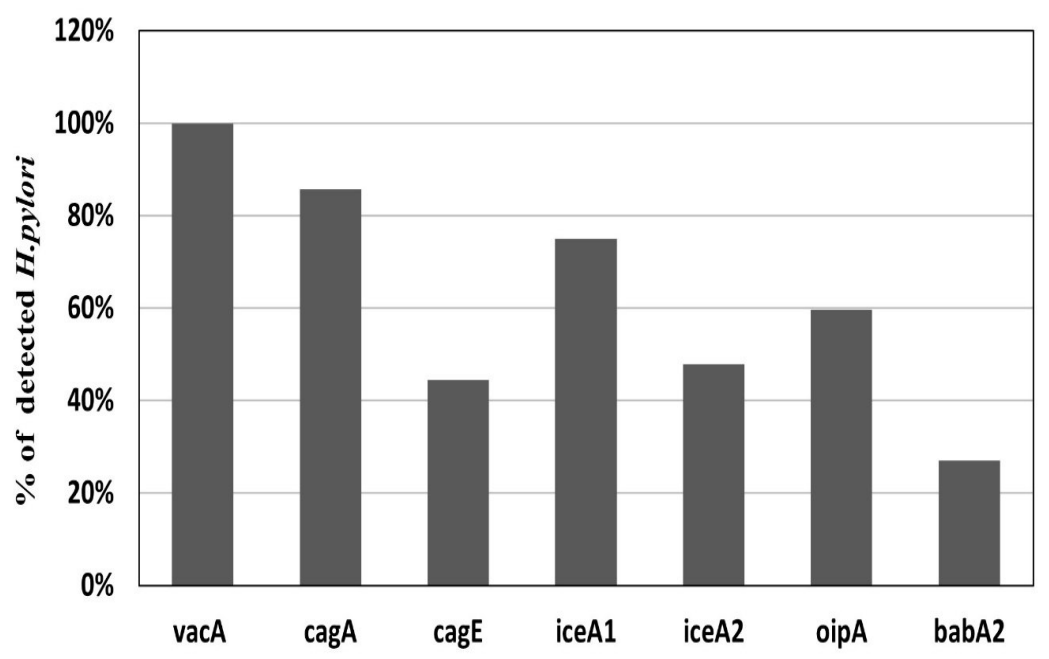

Fig. 2: Frequency of the different virulence-related genes among samples. 
Table 4: Profiles of the different combinations of the virulence genes of $H$. pylori positive specimens.

\begin{tabular}{|c|c|c|c|c|}
\hline Profile No. & Virulence Genes & $\begin{array}{l}\text { No. of } \\
\text { genes }\end{array}$ & $\begin{array}{c}\text { No. of } \\
\text { detected } \\
\text { H. pylori }\end{array}$ & $\%$ \\
\hline (Profile 1) & $s 1, m l, i 1, d 1, c 1, c a g A, i c e A 1$, oipA & 8 & 21 & 22.8 \\
\hline (Profile 2) & sl, m1,il, d1,cagA,iceA1, oipA, bab A2 & 8 & 9 & 9.78 \\
\hline (Profile 3) & $s 1, m 2, i 1, d 1, c 1$, cagA, iceA1,oipA & 8 & 7 & 7.6 \\
\hline (Profile 4) & $s 1, m 1, i 1, d 1$, cagA, cag $E$, ice $A 2$ & 7 & 5 & 5.43 \\
\hline (Profile 5) & sl, $m 1, i 1, d 2$, cagA, cag E, iceA1, iceA2, bab A2 & 9 & 4 & 4.34 \\
\hline (Profile 6) & $s 1, m 1, i 1$, cagA, cag E, iceA2 & 6 & 4 & 4.34 \\
\hline (Profile 7) & $s 1, m 2, i 1$, cag E, iceA2 & 5 & 4 & 4.34 \\
\hline (Profile 8) & s1, m1,il,cagA,iceA1, oipA, bab A2 & 7 & 3 & 3.26 \\
\hline (Profile 9) & sl, il,d1, cagA, cag E, iceA1, iceA2, oipA, bab A2 & 9 & 3 & 3.26 \\
\hline (Profile 10) & $s 1, m 1, i 1$, cagA, cag E, iceA1, iceA2 & 7 & 3 & 3.26 \\
\hline (Profile 11) & $s 1, m 2, i I, d 1$, cagA, cag E, iceA1, iceA2 & 8 & 3 & 3.26 \\
\hline (Profile 12) & $s 1, m 1, m 2$, cag E, iceA2 & 5 & 3 & 3.26 \\
\hline (Profile 13) & $s 1, m l, i l$, cagA, iceAl, oip $A$, & 6 & 2 & 2.17 \\
\hline (Profile 14) & sl, i1, d1, cagA, iceA1, oipA, babA2 & 7 & 2 & 2.17 \\
\hline (Profile 15) & $s 1, m 1, i 1, d 1, c a g A, c a g E, i c e A 1$, ice $A 2$ & 8 & 2 & 2.17 \\
\hline (Profile 16) & $s 1, m 1, i 1, c 1$, cagA, iceA1, ice $A 2$, oip $A$, babA2 & 9 & 2 & 2.17 \\
\hline (Profile 17) & $s 1, m 1, i 1, d 2$, cagA, cag E, iceA1, iceA2 & 8 & 2 & 2.17 \\
\hline (Profile 18) & $s 1, i 2, c 2, \operatorname{cag} E, i c e A 2$ & 5 & 2 & 2.17 \\
\hline (Profile 19) & $s 1, m 2, i 1$, cagA, iceAl, oipA, & 6 & 1 & 1.08 \\
\hline (Profile 20) & $s 1, s 2, m 2, i 1, c 1$, cagA, iceA1, oipA, & 8 & 1 & 1.08 \\
\hline (Profile 21) & $s 1, s 2, m 2, i 1, d 1, c 1$, cagA, iceA1, oipA, & 9 & 1 & 1.08 \\
\hline (Profile 22) & sl, $m 1, i 1, d 1$, cagA, iceAl, oipA, & 7 & 1 & 1.08 \\
\hline (Profile 23) & $s 1, m 1, i 1, d 1, c 1$, cagA, iceA1, iceA2, oipA, bab A2 & 10 & 1 & 1.08 \\
\hline (Profile 24) & sl, $m 1, i 1$, d1,cagA, cag E, iceA1,iceA2,oipA,bab A2 & 10 & 1 & 1.08 \\
\hline (Profile 25) & s1, il, cagA, cag E, iceA2 & 5 & 1 & 1.08 \\
\hline (Profile 26) & s1, il, cag E, iceA2 & 4 & 1 & 1.08 \\
\hline (Profile 27) & $s 1, m 1, m 2, i 1$, cag $E$, iceA2 & 6 & 1 & 1.08 \\
\hline (Profile 28) & $s 1, m 1, m 2, d 2$, cag $E$, ice $A 2$ & 6 & 1 & 1.08 \\
\hline (Profile 29) & $s 1, m 1, m 2, i 2$, cag $E$, iceA2 & 6 & 1 & 1.08 \\
\hline
\end{tabular}




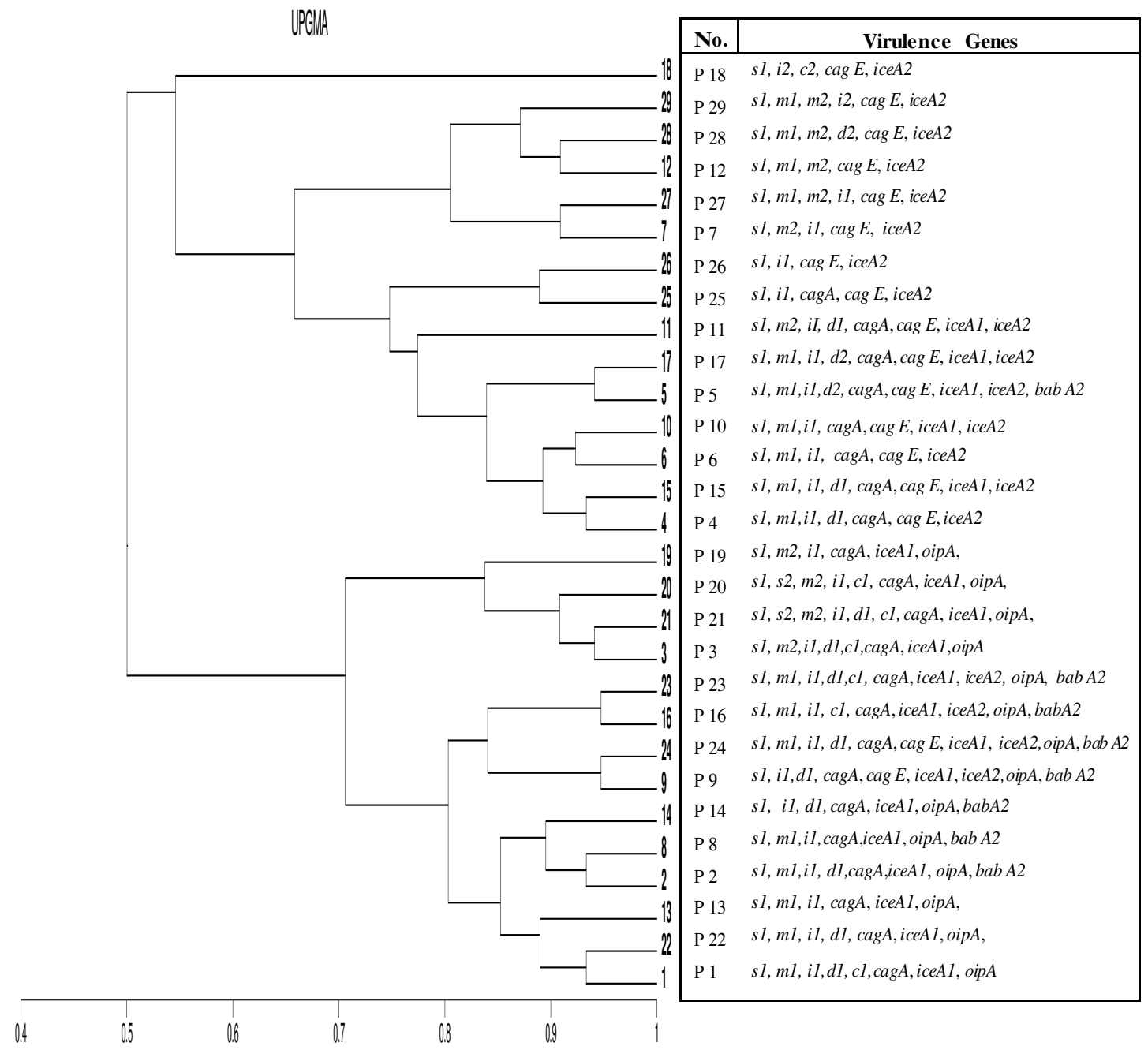

Fig. 3: Dendrogram illustrating the genetic relationship among the 29 genetic profiles of the detected H. pylori.

\section{Discussion}

Previous studies concluded that an invasive test should be used for diagnosis and confirmation of $H$. pylori infections ${ }^{16}$. Invasive upper endoscopy is recommended in the assessment of all patients presenting with dyspepsia with alarm symptoms, including gastrointestinal bleeding, dysphagia, sudden weight loss, as well as unexplained irondeficiency anemia ${ }^{7}$. The symptoms of $H$. pylori infection are affected by different factors, including genetic factors of the host, bacterial virulence determinants and environmental components such as smoking, salt intake, and living conditions ${ }^{8}$. Every H. pylori -positive person has a different strains due to the genetic heterogeneity of $H$. pylori, depending on the ability of this microorganism to adapt to its host's gastric conditions, in addition to the different patterns of the host's immune response to $\mathrm{H}$. pylori infection ${ }^{18}$.

The virulence factors of $H$. pylori have been shown to play a crucial role in determining the course of its associated diseases $^{19 \& 20}$. A more detailed insight into the pathogenesis of $H$. pylori infection can be provided by understanding the mechanisms of these virulence factors and heterogeneity in biological characteristics of infection with $H$. pylori ${ }^{8}$.

Abu-Taleb, et al. ${ }^{11}$ analyzed H. pylori virulence genes from gastric biopsies and their interaction with the clinical symptoms. The low bacterial load, presence of non-culturable coccoid forms, antibiotic therapy, or contamination by other bacteria that suppress 
the growth of $H$. pylori lead to a low detection rate using the culture method $(26.5 \%)$ and false-negative results. Therefore, PCR is a very useful tool for detection of $\mathrm{H}$. pylori in such cases $^{18}$. In the current study, the prevalence of H. pylori infection was $92 / 120(76.6 \%)$ of the collected biopsy specimens in Upper Egypt. This result agrees with the finding of Essawi, et $a l .^{3}$, who observed that in some developing countries, the prevalence of $H$. pylori infection may surpass $70 \%$ which could be explain by the involvement of microbial factors contributing to the pathogenicity of the organism.

VacA gene is a secreted pore-forming toxin that was detected in $92(100 \%)$ in $H$. pylori and used for detection of the bacteria in our study. Our results are consistent with other reports ${ }^{9,21 \& 22}$ that showed that the distribution rate of vacA was $100 \%$ in all $\mathrm{H}$. pylori positive gastric biopsies. In contrast, another study showed that the prevalence of the vacA gene was $40.9 \%$ among positive-H. pylori ${ }^{1}$. VacA plays an important role in the pathogenesis of $H$. pylori infections. It acts as exotoxin protein and that can induce multiple cellular activities, including membrane channel formation, the release of mitochondrial cytochrome $\mathrm{C}$ following pro-inflammatory response activation leading to programmed cell death and binding to cell membrane receptors ${ }^{5,23 \& 24}$. This toxin causes injury to gastric epithelium following progressive vacuolation ${ }^{3}$.

In this study, we analyzed the frequency of the 5 common alleles of the vacA region $s, m, I$, $d$ and, $c$ in $H$ pylori positive samples. All isolates showed mixed genotypes. KoronaGlowniak, et $a l^{18}$ reported that mixed vacA gene types were found in $8 \%$ of the samples that colonize gastric mucosa. In our investigation, the distribution vacA subtypes $s 1 / \mathrm{ml}, \mathrm{sl} / \mathrm{m} 2$ and $s 2 / \mathrm{m} 2$ were $66(71.7 \%), 23$ $(25 \%)$ and $2(2.1 \%)$, respectively. This is in agreement with other previous studies ${ }^{5 \& 21}$, that reported that the most predominant genotype was vacA $s 1 / \mathrm{ml}$ in $57.7 \%$, followed by $s 2 / \mathrm{m} 2$, $s 1 / m 2$ or $s 2 / m 1^{18}$. A previous findings detected $(\operatorname{sim} 0)$ in $4.8 \%$ of samples ${ }^{18}$. The difference in distribution of the vacA subtypes is explained by the regional and ethnic differences ${ }^{24}$. This analysis detected the distribution rate of $\operatorname{cagA}$, cagE, iceA1, and iceA2 virulence genes were expressed at a markedly high rate $79(85.8 \%)$,
41 (44.5\%), 69 (75\%) and 44 (47.8\%) respectively. This result mostly similar to Hemmatinezhad, et al. ${ }^{22}$, investigated that the distribution of cagA, cagE, iceA1, and iceA2, virulence factors were $87.3 \%, 48.5 \%, 47 \%$ and $47 \%$ respectively ${ }^{11 \& 22}$. H. pylori travel from the gastric mucosal epithelium layer to the basal layer, the oipA gene plays a key role in the colonization of this pathogen in the gastric mucosa ${ }^{5}$. The frequency of oipA was $59.7 \%$. In contrast, oipA was detected in $15.2 \%$ in a previous study ${ }^{5 \& 22}$. OipA has been significantly associated with increased IL-8 levels ${ }^{8 \& 25}$.

Regarding the main allelic antigens of iceA, the distribution of iceAl and iceA2 were comparable in $32.3 \%$ and $35.5 \%$ respectively ${ }^{18}$. In the current study we observed that, $b a b A 2$ gene was detected in $25(27.1 \%)$ of $H$. pylori. A similar rate was also shown in other studies $^{21 \& 22}$. There is a relationship between adhesiveness of $H$. pylori to the glycosylated mucins via the blood group antigen-binding adhesion $b a b A$ and associated structures in the gastric mucosa ${ }^{8 \& 26}$.

Our results showed that the most predominant genotype combination was $\operatorname{cag} A$ with vacAs1 This result is consistent with other studies carried out on strains in Europe and in Asian countries ${ }^{11}$. However, a lower rate $(62 \%)$ was reported by Garcia, et al. ${ }^{21}$. cagA and vacA are strongly associated with gastric ulcers, inflammatory effects, IL-8 production, and gastric cancer ${ }^{2 \& 27}$.

Geno-typing using the pattern of virulence markers is one of the best tools to study the correlations between $H$. pylori obtained from different samples ${ }^{5}$. The different types of these gene regions are associated with variability in vacuolation, specificity and clinical symptoms $^{24}$. This investigation detected that the frequency of different alternative combinations of the 10 virulence markers vacA alleles with cagA, cagE, iceA1, iceA2, oipA and babA2 were grouped into 29 different genotypes. Each of these strains carrying mixed virulence genes ranging from at least 4 genes as represented in "Profile 26" to 10 virulence genes that were detected in only 2 samples (Profiles 23 and 24).

We noticed that $s 1 / i 1 / m 1$ was the most prevalent genotype and this result is in agreement with other study by Erzin, et al. ${ }^{28}$ who reported different involving combination 
of vacA gene such as $s 1 / i 1 / \mathrm{m} 1, \quad s 1 / \mathrm{i} 1 / \mathrm{m} 2$, $s 1 / i 2 / m 2$ and $s 2 / i 2 / m 2$ types. The $s 1, m 1$, and $i 1$ types are associated with a higher risk of gastric carcinoma development than the $s 2, m 2$, or $i 2$ types that they are considerably less active and are substantially nontoxic ${ }^{24}$. In our results, the prevalence of vacA il was 85 $(92.3 \%)$ which in agreement with Subsomwong, et al. ${ }^{1}$, who found that the predominant genotype was vacA il (98.6\%). Among our isolates the most predominant profile was "Profile 1" ( $1 / \mathrm{ml} / \mathrm{ill} \mathrm{dl} / \mathrm{cll}$ cagA/ iceA1/oipA) represented in 21 (22.8\%) of the $H$. pylori positive samples with $8 \mathrm{mixed}$ virulence-related genes. This is in agreement with Subsomwong, et al. ${ }^{1}$, who concluded that the $s 1 / m 1 / i 1 / c 1 / d 1$ genotype was the predominant vacA type $32.4 \%$. Analysis of combined genotypes of the vacA alleles and $\operatorname{cag} A$ status in addition to their combination with vacAml, il, dl with $\operatorname{cag} A$ genotypes may play a significant role in determining $H$.pylori-related outcomes of clinical data ${ }^{19 \& 29}$. In addition, H. pylori vacA sla, cagA, and cagE genotypes have remarkable correlations with the presence of duodenal ulcer or gastric carcinoma ${ }^{28}$.

\section{Conclusion}

Our results show a high frequency of $H$. pylori infections among Egyptian patients with gastrointestinal symptoms. The $s 1 / \mathrm{ml} / \mathrm{il}$ vacA hybrid is the most prevalent subtype. The distribution of the different virulence-related genes shows alarming rates of $\operatorname{cagA}, \operatorname{cag} E$, iceA1, iceA2 and oipA. Careful monitory of $H$. pylori infections and investigation of their genetic characters should be carried out to control the spread of the virulent strains.

\section{Ethical approval}

A written patient's consent was obtained prior to registration from all participants in this study. The study protocol was in agreement with the Helsinki Declaration and was approved by the Ethics Committee in Human Research of Faculty of Medicine, Assiut University, Egypt (IRB No 17300569).

\section{Competing interests}

The authors declare that they have no competing interest "None declared".

\section{REFERENCES}

1. P. Subsomwong, M. Miftahussurur, T. Uchida, R. K. Vilaichone, T. Ratanachuek, V. Mahachai, et al., "Prevalence, risk factors, and virulence genes of Helicobacter pylori among dyspeptic patients in two different gastric cancer risk regions of Thailand", PLoS ONE, 12, e0187113 (2017).

2. J. G. Kusters, A. H. Van. Vliet and E. J. Kuipers, "Pathogenesis of Helicobacter pylori infection", Clinical Microbiology Reviews, 19, 449-490 (2006).

3. T. Essawi, W. Hammoudeh, I. Sabri, W. Sweidan and M. A. Farraj, "Determination of Helicobacter pylori virulence genes in gastric biopsies by PCR", ISRN Gastroenterology, 2013, (2013).

4. H. Baradari, Z. Mashak and B. TavakoliFar, "Vacuolating cytotoxin A (vacA) and cytotoxin-associated gene A (cagA) genotypes of resistant Helicobacter pylori strains isolated from raw and pasteurized milk", Journal of Food Safety, (2019).

5. R. Ranjbar and M. Chehelgerdi, "Genotyping and antibiotic resistance properties of Helicobacter pylori strains isolated from human and animal gastric biopsies", Infection and Drug Resistance, 11, 2545 (2018).

6. S. Vannarath, R-k. Vilaichone, B. Rasachak, P. Mairiang, Y. Yamaoka, S. Shiota, et al., "Virulence genes of Helicobacter pylori in gastritis, peptic ulcer and gastric cancer in Laos", Asian Pac. J. Cancer Prev., 15, 9027-9031 (2014).

7. I. Thung, H. Aramin, V. Vavinskaya, S. Gupta, J. Park, S. Crowe, et al., "the global emergence of Helicobacter pylori antibiotic resistance", Alimentary Pharmacology \& Therapeutics, 43, 514533 (2016).

8. D. N. Sgouras, T. T. H. Trang and Y. Yamaoka, "Pathogenesis of Helicobacter pylori infection" Helicobacter, 20, 8-16 (2015).

9. M. Elhariri, D. Hamza, R. Elhelw and E. Hamza, "Occurrence of $\operatorname{cagA}(+)$ vacA s1a $\mathrm{m} 1$ i1 Helicobacter pylori in farm animals in Egypt and ability to survive in 
experimentally contaminated UHT milk", Sci. Rep., 8, Article No. 14260 (2018).

10. M. Alboraie, W. El-Hossary, D. Ghaith and M. Elzahry, "Extragastroduodenal Manifestation of Helicobacter pylori in Egyptian Children and Adults", Helicobacter: Wiley 111 River St, Hoboken 07030-5774, NJ USA (2017).

11. A. M. Abu-Taleb, R.S. Abdelattef, A. A. Abdel-Hady, F. H. Omran, L. A. ElKorashi, A. A. El-hady, et al., "Prevalence of Helicobacter pylori cagA and iceA genes and their association with gastrointestinal diseases", International Journal of Microbiology, 2018, (2018).

12. K. B. Mansour, C. Fendri, M. Zribi, A. Masmoudi, M. Labbene, A. Fillali, et al., "Prevalence of Helicobacter pylori vacA, cagA, iceA and oipA genotypes in Tunisian patients", Annals of Clinical Microbiology and Antimicrobials, 9, Article No. 10 (2010).

13. M. Keikha, "Is there a relationship between Helicobacter pylori vacA i1 or i2 alleles and development into peptic ulcer and gastric cancer? A meta-analysis study on an Iranian population", New Microbes and New Infections, 36, 100726 (2020).

14. X. Huang, Z. Deng, Q. Zhang, W. Li, B. Wang and M. Li, "Relationship between the iceA gene of Helicobacter pylori and clinical outcomes", Therapeutics and Clinical Risk Management, 12, 1085 (2016).

15. D. Ilver, A. Arnqvist, J. Ögren, I-M. Frick, D. Kersulyte, E.T. Incecik, et al., "Helicobacter pylori adhesin binding fucosylated histo-blood group antigens revealed by retagging", Science, 279, 373377 (1998).

16. A. M. Abu-Taleb, R. S. Abdelattef, A. A. Abdel-Hady, F. H. Omran, L. A. ElKorashi, A. A. El-hady, et al., "Prevalence of Helicobacter pylori cagA and iceA genes and their association with gastrointestinal diseases", International Journal of Microbiology, 2018, (2018).

17. M. Nei and W. H. Li, "Mathematical model for studying genetic variation in terms of restriction endonucleases", Proc. Natl. Acad. Sci. U S A, 76, 5269-5273 (1979).
18. I. Korona-Glowniak, H. Cichoz-Lach, R. Siwiec, S. Andrzejczuk, A. Glowniak, P. Matras, et al., "Antibiotic resistance and genotypes of Helicobacter pylori strains in patients with gastroduodenal disease in Southeast Poland", J. Clin. Med., 8 (2019).

19. S. Z. Bakhti, S. Latifi-Navid, S. Mohammadi, S. Zahri, F. S. Bakhti, F. Feizi, et al., "Relevance of Helicobacter pylori vacA 3'-end Region Polymorphism to Gastric Cancer", Helicobacter, 21, 305316 (2016).

20. Z. Basiri, R. Safaralizadeh, M. J. Bonyadi, M. H. Somi, M. Mahdavi and S. Latifi-Navid, "Helicobacter pylori vacA d1 genotype predicts risk of gastric adenocarcinoma and peptic ulcers in northwestern Iran", Asian Pac. J. Cancer Prev., 15, 1575-1579 (2014).

21. G. T. Garcia, K. R. Aranda, M. E. Goncalves, S. R. Cardoso, K. Iriya, N. P. Silva, et al., "High prevalence of clarithromycin resistance and cagA, vacA, iceA2, and babA2 genotypes of Helicobacter pylori in Brazilian children", J. Clin. Microbiol., 48, 4266-4268 (2010).

22. B. Hemmatinezhad, H. Momtaz and E. Rahimi, "Antimicrobials. VacA, cagA, ice A and oipA genotypes status and antimicrobial resistance properties of Helicobacter pylori isolated from various types of ready to eat foods", J. Annals of Clinical Microbiology, 15, 1-9 (2016).

23. Y. Yamaoka, S. Kikuchi, H. M. ElZimaity, O. Gutierrez, M. S. Osato and D. Y. Graham, "Importance of Helicobacter pylori oipA in clinical presentation, gastric inflammation, and mucosal interleukin 8 production", Gastroenterology, 123, 414-424 (2002).

24. Y. Yamaoka, "Mechanisms of disease: Helicobacter pylori virulence factors", Nat. Rev. Gastroenterol. Hepatol., 7, 629641 (2010).

25. R. Rad, M. Gerhard, R. Lang, M. Schoniger, T. Rosch, W. Schepp, et al., "The Helicobacter pylori blood group antigen-binding adhesin facilitates bacterial colonization and augments a nonspecific immune response", $\boldsymbol{J}$. Immunol., 168, 3033-3041(2002). 
26. E. C. Skoog, M. Padra, A. Aberg, P. Gideonsson, I. Obi, M. P. QuintanaHayashi, et al., "BabA dependent binding of Helicobacter pylori to human gastric mucins cause aggregation that inhibits proliferation and is regulated via ArsS", Sci. Rep., 7, Article No. 40656 (2017).

27. N. Yilmaz and M. Koruk Ozer, "The Prevalence of Helicobacter pylori babA, homB, aspA, and sabA Genes and Its Relationship with Clinical Outcomes in Turkey", Can. J. Gastroenterol. Hepatol., 2019, Article ID1271872 (2019).
28. Y. Erzin, V. Koksal, S. Altun, A. Dobrucali, M. Aslan, S. Erdamar, et al., "Prevalence of Helicobacter pylori vacA, cagA, cagE, iceA, babA2 genotypes and correlation with clinical outcome in Turkish patients with dyspepsia", Helicobacter, 11, 574-580 (2006).

29. S. Z. Bakhti, S. Latifi-Navid and S. Zahri, "Unique constellations of five polymorphic sites of Helicobacter pylori vacA and cagA status associated with risk of gastric cancer", Infect. Genet. Evol., 79, 104167 (2020). 


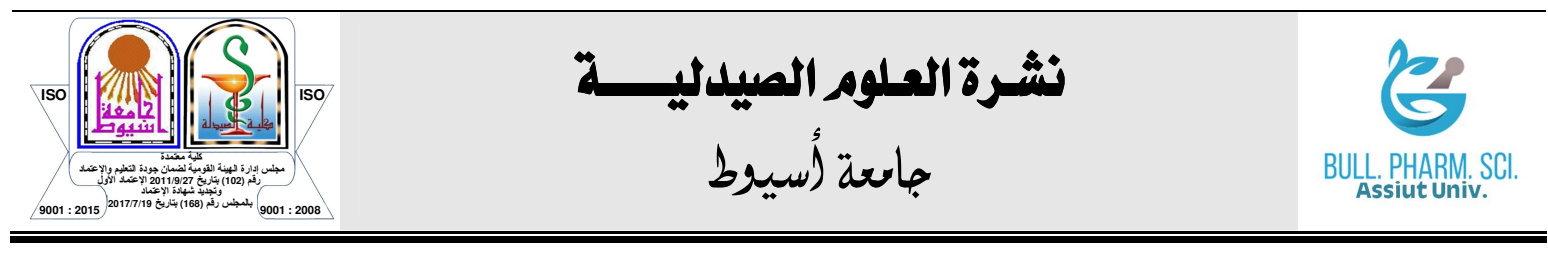

\section{ملامح أوجه شراسة الهيليكوباكتر بيلوري التي تم اكتشافها في خزعات المعدة

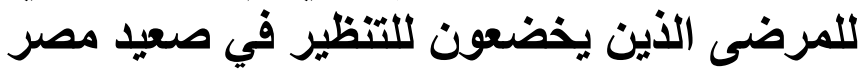

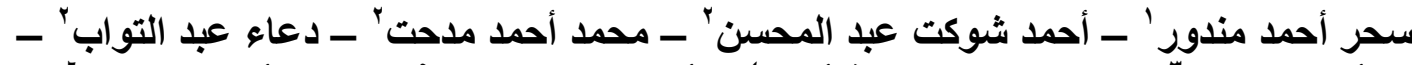

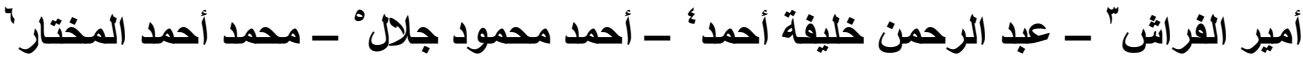

'قسم الميكروبيولوجيا والمناعة ، كلية الصيدلة ، جامعة دراية ، المنيا 111117 ، ، مصر

'قسم طب المناطق الحارة والجهاز الهضمي ، كلية الطب ، جامعة أسيوط ، أسيوط ، مصر

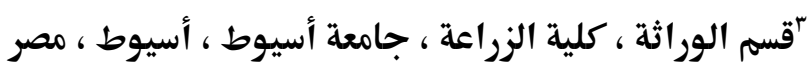

عُالب طب ، كلية الطب ، جامعة أسيوط ، أسيوط ، مصر كاله

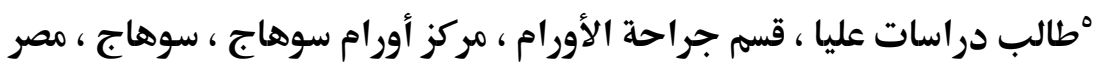

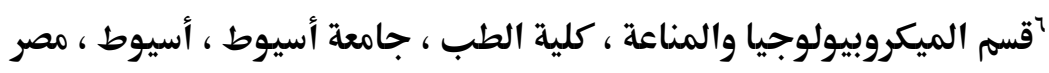

الخلفية: ميكروب الهيليكوباكتر بيلوري او جرثومه المعده هي سبب شـائع لقرحة المعدة وهي عامل خطر

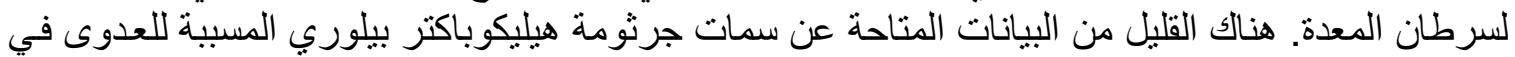

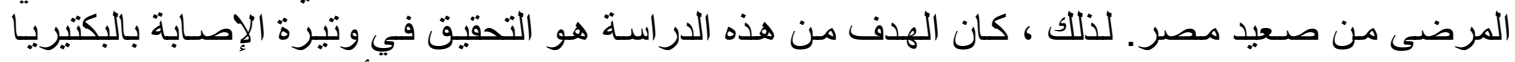

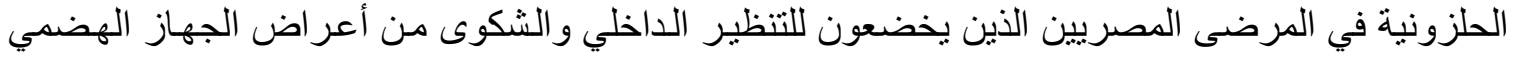

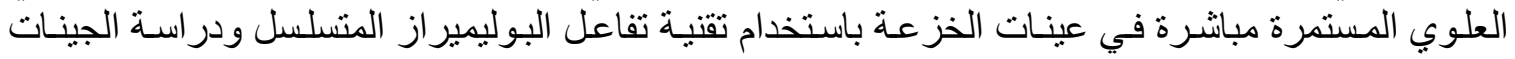
المرتبطة باوجه الشراسه في هيليكوباكتر بيلوة الئوري الموجبة.

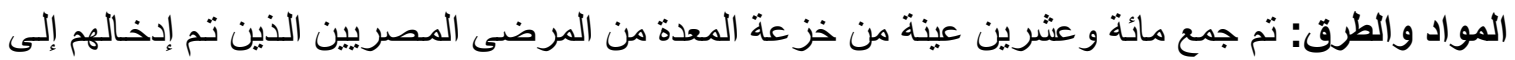

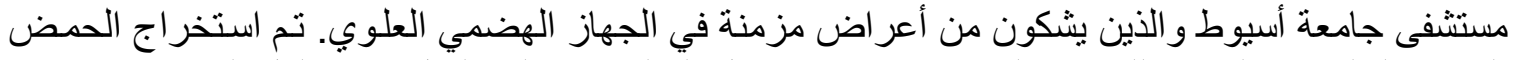

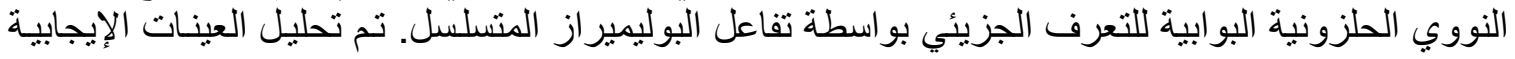

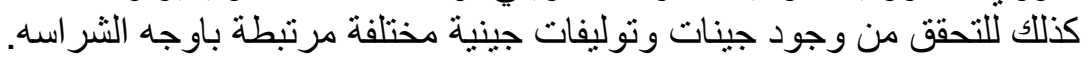

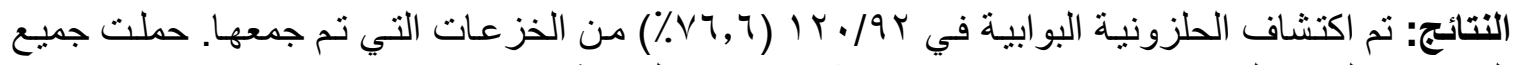

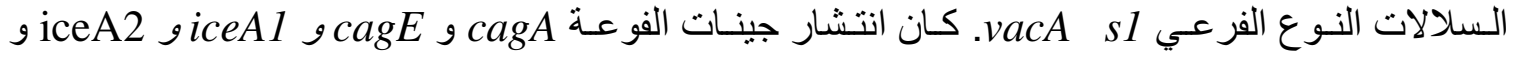
oipA 79

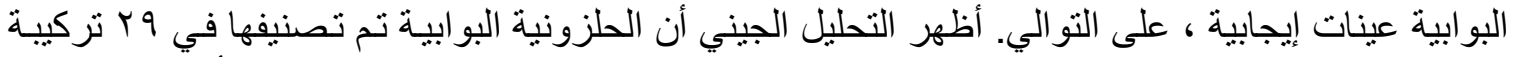

ور اثية مختلفة. كان النمط الجيني s1 / m1 / il / d1 / c1 / cagA / iceA1 / oipA هو الأكثر انتشارًا.

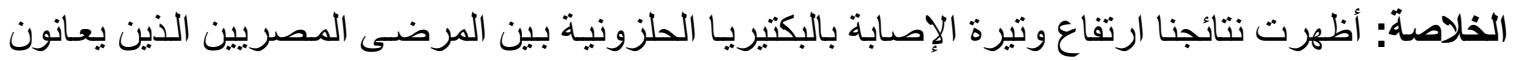

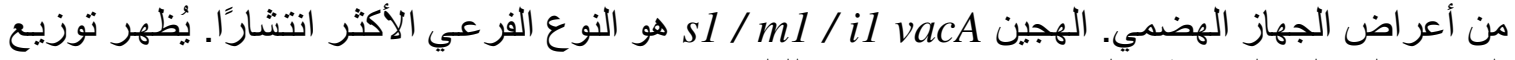

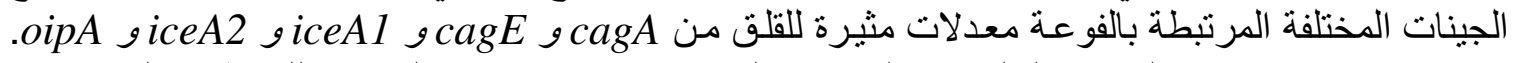

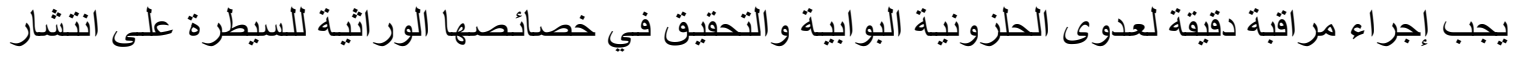

